\title{
Identification of the Immunoreactive-Neurophysin Cells in the Ovary of the Albino Rats Using an Immunoperoxidase Method
}

\author{
Daryanto
}

\begin{abstract}
Abstrak
Penelitian ini bertujuan untuk mengidentifikasi apakah benar hormon oksitosin dan vasopresin juga disintesis di dalam ovarium tikus putih, melalui tahap molekul-pendahulunya, neurofisin, dengan menggunakan salah satu metode imunoperoksidase dan antibodi primer neurofisin. Dua puluh ekor tikus putih (Rattus norvegicus) dewasa, betina, galur Lembaga Makanan Rakyat (LMR) Jakarta, berat antara 150-250 g digunakan pada penelitian ini. Tikus dibagi menjadi 2 kelompok, kelompok pertama terdiri atas 10 ekor tikus putih, tanpa diberikan perlakuan apa-apa, kemudian tikus dibunuh dengan cara dekapitasi, dibuat sediaan mikroskopik ovarium yang diwarnai dengan metode pewarnaan imunoperoksidase menggunakan labelled streptavidin-biotin (LSAB) kit dan antibodi primer terhadap neurofisin (1\% rabbit anti-human-neurophysin dalam larutan 3\% serum kuda normal). Kelompok kedua, terdiri atas 10 ekor tikus putih, diberi perlakuan puasa air selama 5 hari berturut-turut; usai perlakuan semua tikus dibunuh dengan cara dekapitasi, dan dibuat sediaan mikroskopik ovarium yang diwarnai dengan metode imunoperoksidase sama seperti dilakukan pada tikus kelompok pertama. Hasil menunjukkan bahwa ovarium, terutama pada korpus luteum, memberikan reaksi positif terhadap teknik pewarnaan imunoperoksidase. Reaksi positif ini berupa reaksi coklat (brown reaction) dan terdapat di dalam sel (intraseluler). Dengan demikian dapat diambil kesimpulan bahwa hormon vasopresin dan oksitosin disintesis di dalam korpus luteum ovarium melalui tahap molekulpendahulunya, neurofisin.
\end{abstract}

\begin{abstract}
The objective of this investigation is to identify whether the oxytocin and vasopressin hormones were synthesized in the ovary of the albino rats, via their precursor-molecules phase, neurophysin, by using one of the immunoperoxidase staining methods and anti-neurophysin as a primary antibody. Twenty adult female albino rats of the Lembaga Makanan Rakyat (LMR) strain, weighing between $150-250 \mathrm{~g}$ were used in this investigation, and divided into two groups. The first group consisting of 10 adult albino rats, without any treatment were killed by decapitation and microscopic slides of the ovary were stained by immunoperoxidase staining methods, using $1 \%$ rabbit anti-human-neurophysin in $3 \%$ normal horse serum (NHS) solution, as primary antibody and labelled streptavidin-biotin (LSAB) kits. The second group, consisting of 10 adult albino rats, were given a five-day consecutive water fasting treatment, killed by decapitation, and microscopic slides of the ovary were stained also by immunoperoxidase staining method as mentioned above. The results revealed that the ovary, especially the corpus luteum, gave a positive reaction (brown reaction) intracellularly by immunoperoxidase staining method. These results indicate that vasopressin and oxytocin hormones were synthesized in the ovary, via the precursor molecules phase, the neurophysins.
\end{abstract}

Keywords : Oxytocin, vasopressin, neurophysin, neurosecretion neurosecretory cells, ovary, immunoperoxidase.

\section{INTRODUCTION}

Neurophysins are large peptide molecules, of still unknown biologic action, that are synthetized by neurons of the posterior pituitary and secreted together with the hormones vasopressin and oxytocin, ${ }^{1}$ as neurosecreta. ${ }^{2,3,4,5}$ Historically the neurophysins occupy a pivotal point in the understanding of neurosecretion. ${ }^{1}$ The historical significance of the neurophysins is at- tributable to their high cystein content, which gives them an affinity for chrome alum hematoxylin stain developed by Gomori. According to Bargmann, Scharrer and Scharrer, the secretory material of the posterior pituitary, which gave a positive reaction by Gomori's staining method, known as the Van Dyke protein, was synthetized in clusters of cells (neurons) in the hypothalamus, and the terminal of the long axons of these neurons ended on blood vessels rather than in 
synapses with other neurons. This finding provided the definitive anatomic evidence that in addition to secreting neurotransmitters into the perineural space, these nerve cells secrete substances into the bloodstream, firmly establishing the concept of neurosecretion.

The term neurosecretory cell was introduced by Knowles (1965) and later used at the VIth Symposium on neurosecretion in 1974 in London. Neuro-secretory cell means a neuron and its axon that had to be stained selectively with chrome hematoxylin, terminate on blood vessels of the posterior lobe and release its secretion into the bloodstream. Scharrer (1965) tried to give a better definition of a neurosecretory cell including all known and accepted properties: special staining affinities, the presence of elementary granules, no synaptic junctions, either with other neurons or with other target cells, and the release of its product into the blood stream. ${ }^{2}$

Neurophysins are secreted into the blood along with the hormones, and there is a specific neurophysin for vasopressin and a different and specific neurophysin for oxytocin. By using immunohistochemical techniques it has been shown that neurophysins are associated with the posterior pituitary hormones throughout the entire neurosecretory system, from the sites of synthesis of the hormones in the supraoptic and paraventricular nuclei of the hypothalamus to the sites of release in the neurohypophysis. Once synthetized, neurophysin and hormone are packaged together in the neurosecretory granule where they are held together by noncovalent binding. ${ }^{1}$

In man, two neurophysins have been demonstrated by specific radioimmunoassay, and it now seems that one is a vasopressin neurophysin and the other is an oxytocin neurophysin. According to the stimuli which provoked their secretion, there were nicotinestimulated neurophysin (NSN) and estrogen-stimulated neurophysin (ESN).

Oxytocin and vasopressin are typical neuronal hormones, j.e. hormones secreted into the circulation by nerve cells. The term neurosecretion was originally coined to describe the secretion of hormones by neurons. 5

Like other peptide hormones, both oxytocin and vasopressin have a characteristic neurophysin associated with the granules in the neurons which secrete them, neurophysin I in the case of oxytocin and neurophysin II in the case of vasopressin. The neurophysins were originally thought to be binding polypeptides, but now it appears that they are simply parts of the precursor molecules. The precursor for vasopressin is prepropressophysin and the precursor for oxytocin is prepro-oxyphysin..$^{5}$ (see MJUI vol. 3 number 3 September 1994).

The aim of this descriptive-explorative investigation was to identify whether the vasopressin and oxytocin hormones were synthesized in the ovary, via the precursor molecules phase, the neurophysins, by utilizing an immunoperoxidase staining method and anti neurophysin as the primary antibody.

\section{MATERIALS AND METHODS}

Twenty adult female albino rats of the Lembaga Makanan Rakyat (LMR) strain weighing between 150 $250 \mathrm{~g}$, were used in this experiment and divided into two groups. The first group consisted of 10 adult albino rats without any treatment, and the second group consisting of 10 adult albino rats were given a five consecutive day water fasting treatment.

All of the rats, in the first and second group, were killed by decapitation and microscopic slides of the ovary were stained by the immunoperoxidase staining method.

This investigation used one of the immunohistochemical methods, i.e. the immunoperoxidase method, and was based on the assumption of the production of neurosecretoric materials (vasopressin and oxytocin hormones). The immunoperoxidase method, is based on the reaction of antigen-antibody complexes. This investigation used $1 \%$ rabbit antihuman-neurophysin in $3 \%$ normal horse serum (NHS) solution, as a primary antibody, and labelled streptavidin-biotin ( $L S A B)$ kits.

The staining procedure used in this investigation is one of the many immuno-enzymatic staining methods, i.e. a two-step indirect method using labelled streptavidin-biotin kit on paraffin embedded section." 6 This method utilizes the high affinity of avidin or streptavidin for biotin. Avidin has four binding sites for biotin. This method requires a biotinylated antibody as a link antibody ${ }^{6}$. In this investigation the rabbit anti-human-neurophysin from DAKO Corporation, USA was used as a primary antibody.

\section{RESULTS}

The result of this investigation revealed that the ovary gave a positive reaction (brown reaction) especially in the corpus luteum and the location of the positive reaction was intracellular (Figure 1). However, other components of the ovary did not give a positive reaction (Figure 2). Figure 3 showed a negative control of the corpus luteum. 


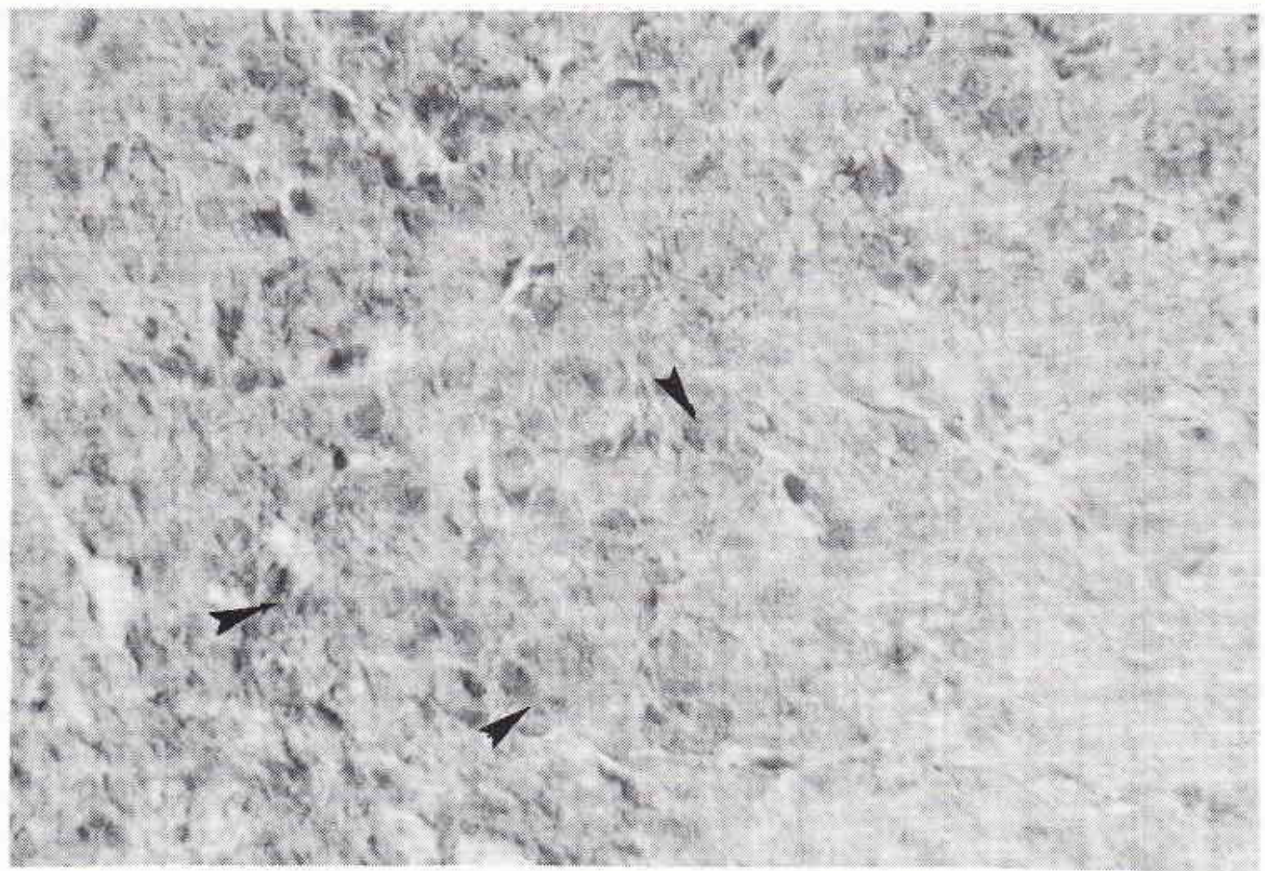

A.

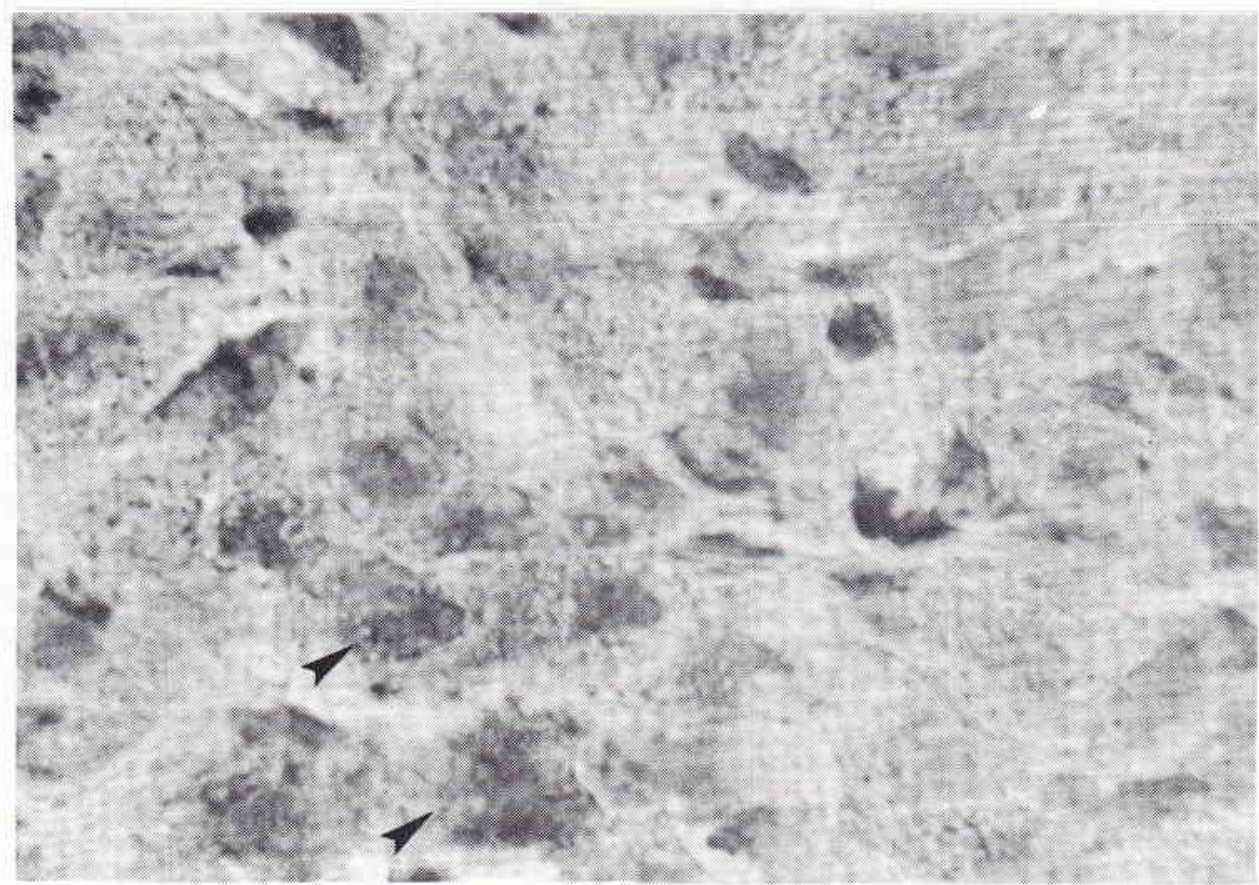

B.

Figure 1. Photomicrographs of a sagittal view of the corpus luteum of the rat ovary, showing the example of the sites of positive reaction (brown reaction) to the labelled streptavidin-biotin staining method (LSAB). The location of the brown reaction is intracellular. (A) $\times 400$ and (B) $\times 1000$. 


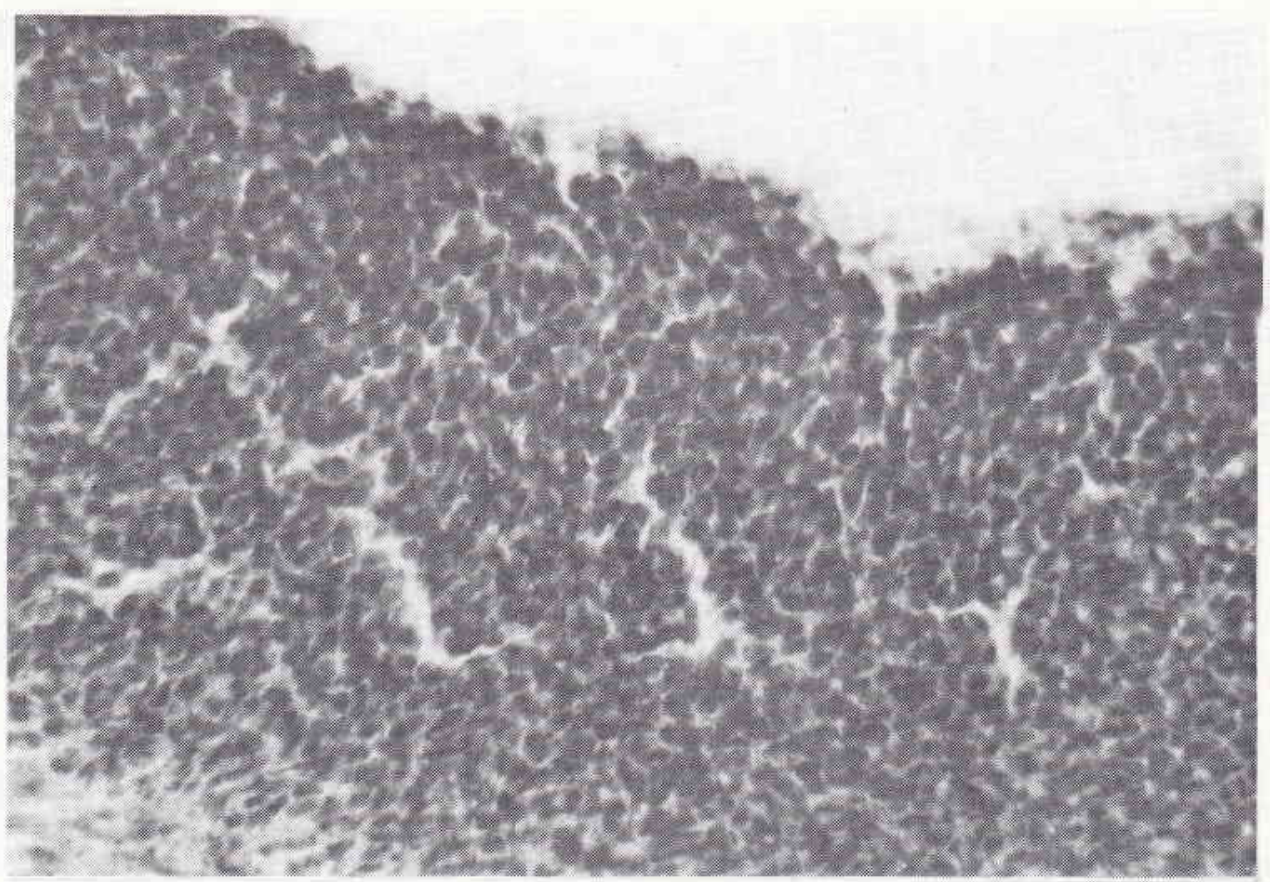

A.

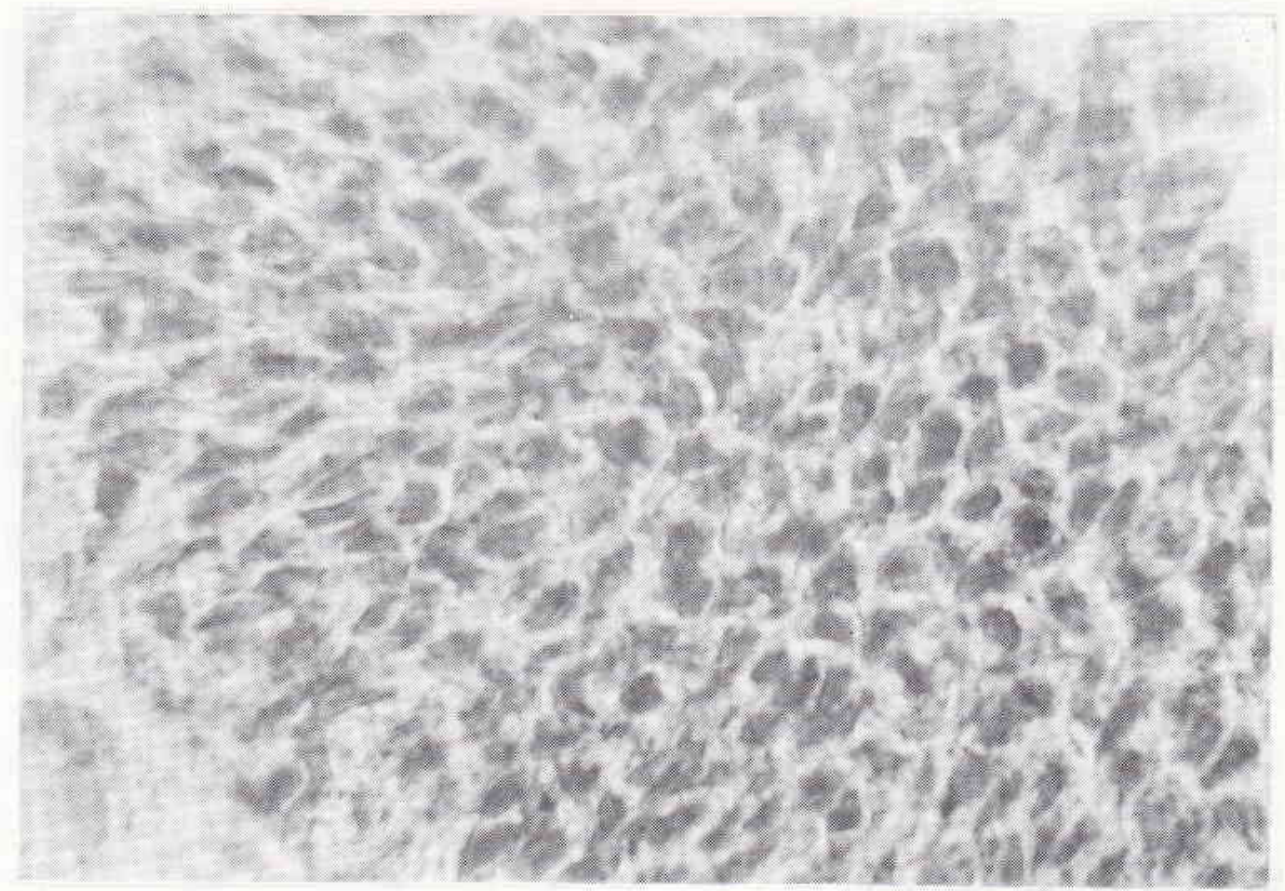

B.

Figure 2. Photomicrographs of a sagittal view of the rat mature follicle (Graafian follicle), showing the example of a negative reaction to the labelled streptavidin-biotin staining method (LSAB). (A) X 400 and (B) X 1000 . 


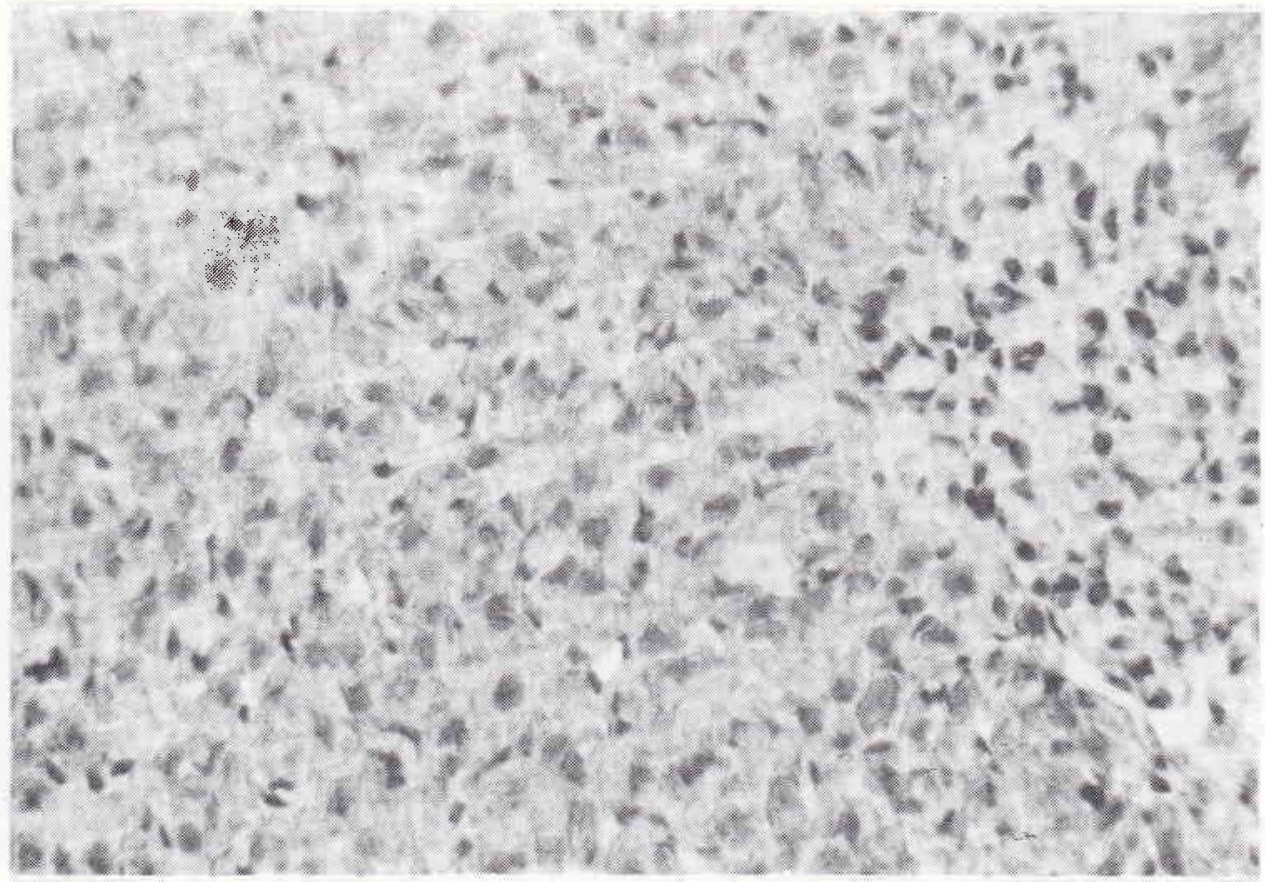

A.

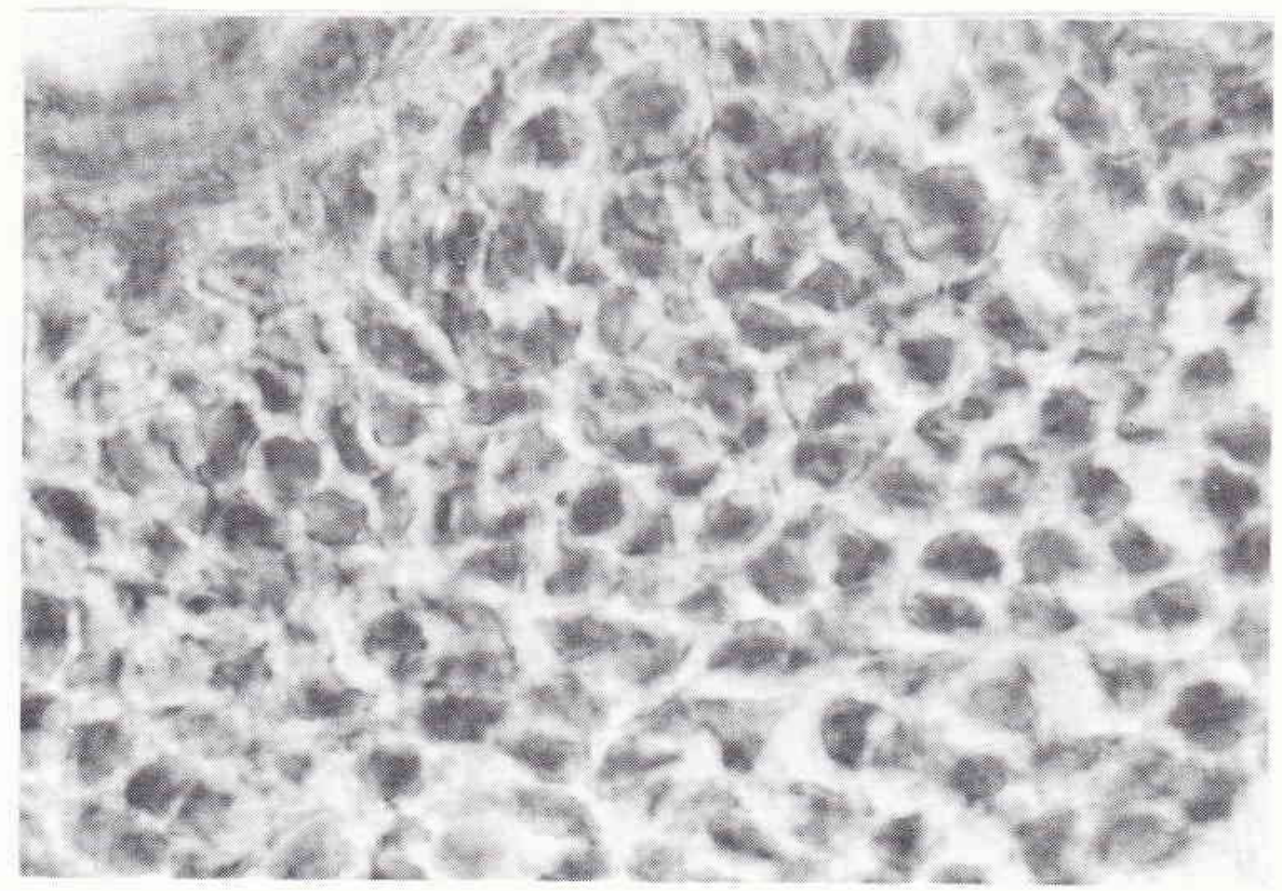

B.

Figure 3. Photomicrographs of a sagittal view of the corpus luteum and mature follicle of the rat ovary, showing a negative-control, stained by the LSAB staining method, without adding a primary antibody. (A) X 400 and $(B) \times 1000$. 
The result of this investigation showed that both the first and the second group gave the same brown reaction (Table 1 ).

Table 1. The comparison of the density and intensity of the positive-reaction (brown reaction) in the ovary of the rats, without treatment and a five consecutive days water fasting treatment

\begin{tabular}{rcc}
\hline & \multicolumn{2}{c}{ Brown-reaction score } \\
\cline { 2 - 3 } Rats number & without treatment & with treatment \\
\cline { 2 - 3 } I & ++++ & ++++ \\
II & ++++ & ++++ \\
III & ++++ & ++++ \\
IV & ++++ & ++++ \\
V & ++++ & ++++ \\
VI & ++++ & ++++ \\
VII & ++++ & ++++ \\
VIII & ++++ & ++++ \\
IX & ++++ & ++++ \\
X & ++++ & ++++ \\
\hline
\end{tabular}

\section{DISCUSSION}

In this investigation an identification of the immunoreactive- neurophysin cells in the ovary of the rats were verified using one of the immunoperoxidase methods, according to Naish et al. ${ }^{6}$ and Taylor \& Bennington. ${ }^{7}$ The cells in the ovary, especially in the corpus luteum, showed a positive response by giving a brown reaction. The location of the brown reaction was intracellular. This result revealed that the ovary contained neurosecretoric materials, which was positive to the immunoperoxidase method. In this study we used rabbit anti-human-neurophysin as a primary antibody, and LSAB kit; the biotin linked to the primary antibody, produced a biotinylated conjugate which, when added to the tissue section, localized the site of antigen within the section. ${ }^{7}$ The neurophysin is a precursor molecule of vasopressin and oxytocin hormones. ${ }^{5}$ The existence of neurosecretoric materials intracellularly, proved that these materials were synthetised and produced by the cells in the corpus luteum of the ovary. This result supports and clarifies Ganong's 5 finding, that vasopressin and oxytocin are synthesized in the gonads; but Ganong did not describe the exact location of the synthesis.
The microscopic feature of this finding was rather different from Daryanto's ${ }^{8}$ finding, in which the supraoptic and paraventricular nuclei showed very clear positive reactions. The cause might be that the concentration of the vasopressin and oxytocin hormones in the corpus luteum was less than in those nuclei.

In addition, there were no differences in the density and intensity of the positive reaction (brown reaction) between rats without treatment and rats given a five consecutive day water fasting treatment.

\section{CONCLUSION}

By immunoperoxidase method using anti-neurophysin as a primary antibody and LSAB kits, it is proved that vasopressin and oxytocin hormones are also synthesized in the ovary via their precursor molecules, the neurophysins.

\section{Acknowledgement}

My thanks are directed to Direktur Pembinaan Penelitian dan Pengabdian pada Masyarakat, Ditjen Dikti Depdikbud, jl. Pintu I, Senayan Jakarta for the fund granted through the contract number 0.40.5/P4M/DPPM/L.3311/94/BBI/1994.

\section{REFERENCES}

1. Robinson AG. Neurophysins and their physiologic significance. In: Krieger DT, Hughes JC, editors. Neuroendocrinology. Sunderland: Sinauer, 1980: 149-55.

2. Stutinsky $\mathbf{F}$. The place of neurosecretion in modern neurobiology. In: Vincent JD, Kordon C, editors. Cell biology of hypothalamic neurosecretion. Paris: Du Centre National De La Recherche Scientifique, 1978.

3. Fawcett DW. A textbook of histology. 11th ed. Philadelphia: Saunders, 1986.

4. Cormack DH. Ham's histology. 9th ed. Philadelphia: Lippincott, 1987.

5. Ganong WF. Review of medical physiology. Los Altos: Lange Medical, 1993.

6. Naish SJ, Boenisch T, Farmilo AJ, Stead RH. Handbook of immunochemical staining methods. Denmark: DAKO, 1989.

7. Taylor CR, Bennington JL. Immunomicroscopy: a diagniostic tool for the surgical pathologist. Philadelphia: Saunders, 1986.

8. Daryanto. Tracing the neural connections between the subfornical organ and the supraoptic and paraventricular nuclei using neuroanatomical-tract tracing and immunoperoxidase methods in albino rats. Med J Univ Indones 1994; 3:136-47. 